Ariana Nefat*

Dragan Benazić**
JEL Classification : M31, M39, Q54

Professional paper

https://doi.org/10.32910/ep.70.5.3

\title{
THE STUDENT PERCEPTIONS, CONCERN AND KNOWLEDGE WITH REGARD TO CLIMATE CHANGES IN CROATIA
}

The aim of the paper is to discover the student perceptions of climate changes, so the sample including the Croatian students of economics has been used. The paper contains the evaluation of the importance given to climate changes in relation to other humankind problems, research on the perceptions of the main causes, serious character of the phenomenon, concerns, perceived knowledge, evaluation of sources from which their knowledge has been acquired during education, as well as their openness to new information. When related to the population of students and the complete population, the main findings do not significantly deviate from those in the recent studies of the same kind. However, compared to the earlier research on the complete population sample, this study indicates that some advancement in understanding climate changes can be noticed. The theoretical part surveys the given issue, from viewing climate changes as the world problem to presenting the trendy perceptions of the complete population; it also comprises the perceptions that are based on some studies including the complete population and the population of students in particular. The practical implication would be that, starting from their awareness of how serious climate

* A. Nefat, Ph.D., Associate Professor, Juraj Dobrila University of Pula, "Dr. Mijo Mirković" Faculty of Economics and Tourism in Pula (e-mail: anefat@unipu.hr).

** D. Benazić, Ph.D., Associate Professor, Juraj Dobrila University of Pula, "Dr. Mijo Mirković" Faculty of Economics and Tourism in Pula (e-mail: dbenazic@unipu.hr).

The paper was received on June 28th, 2018. It was accepted for publication on Februrary 11th, 2019. 
changes are and willingness to learn more about climate changes, students should be provided with more comprehensive education to become, as future academic citizens, able to make relevant decisions on the environmental issues. The limitation of the paper refers to the small sample including the students of economics, and the original quality of the study lies in the uniquely determined issues resulting from a combination with a number of previous studies, also contributing to the research into student perceptions of climate changes. Based on the included items, further research into their relationships is recommended.

Key words: climate changes, perceptions, students, Croatia

\section{Introductory considerations}

One's existence is too much tightly linked to the environment in which one lives. The humankind has encountered numerous problems during its evolution, in which process technology brought many advancements although was unable to solve the basic humankind problems at the same time. Some problems, such as the global inequality between people, are even getting worse, while the frenzied demand for mass production and often uncontrolled consumption that is mostly favourable to developed countries result in the devastated environment. The phenomenon which is less observable in everyday life, but which has deep and irreversible consequences on the environment, refers to climate changes. The consequences of climate changes are present all over the world, being multifaceted and complex, such as: ice melting and increase in the sea level, extreme weather conditions, risk to which animals and plants are exposed, health risk and human life risk, as well as the economic consequences (European Commission). The climate changes have also been recognised in Croatia, already showing its consequences, so - in the future - along with some positive effects, they might have significant negative effects on people's health, natural eco-systems and bio-diversity, water and sea resources, forestry, fishing and mar culture, agriculture, tourism, energy, and the coastal part (Landau, Legro \& Vlašić, 2008, Ministarstvo zaštite okoliša i energetike/ Ministry of Environment and Energy, 2017).

The awareness of climate changes, as well as the perception and understanding of them, are the foundations for making changes in the society, the changes needed to mitigate climate changes and to enable our adaptation to the new situation. The research on the given issues has been conducted for several decades; however, researchers, international organisations, governments, and non-profit organisations, along with citizens themselves, have not done enough to stop the 
growth of unfavourable climate changes. The aim of this paper is, therefore, to discover the approach towards climate changes by determining the student perceptions, concern and knowledge with regard to climate changes since this particular population represent an important social group having a potential strength to take some new steps for dealing with the changes.

The first part considers the perception of climate changes as related to other humankind problems, whereas the second part surveys the research on the perceptions of climate changes in the world - first in relation to the relevant trends and then with regard to the insights into particular studies that have been previously conducted using the complete population. Since there are significantly fewer studies on the student perceptions in the world, the given survey presents only the ones that are available. The empirical section contains the results obtained from the students of economics, to be followed by the discussion, paper contribution and limitations, and suggestion for the future research.

\section{Climate Changes As the World Problem}

Despite the significance of environmental problems and climate changes for the humankind, these are considered to be not a primary but an important problem, as many studies in the world have shown. A study, conducted in 33 countries across the world in 2010 (Smith, Kim, \& Son, 2017), confirms that the environmental issues place sixth when it comes to national averages with regard to the concern about certain problems, i.e. behind economy, health care, education, poverty and crime. The environmental care is the strongest in Norway, Switzerland and Canada, while Croatia is at the lower end being $29^{\text {th }}$-ranked. Taking into account all the environmental problems mentioned here ( 9 of them in total), air pollution comes first to be followed by climate changes that are first-ranked in 10 countries, and fifth-ranked in Croatia. Based on the averages concerned with the rest of 6 environmental questions, Japan records the highest percentage of the participants who consider climate changes to be extremely dangerous, while Croatia is a bit below the average being $19^{\text {th }}$-ranked.

According to the Special Euro barometer 459 study about climate changes (European Commission /EC/, 2017), 12\% of the participants view climate changes as the biggest humankind problem, mentioning them third, behind poverty, lack of food and drinking water, and international terrorism. Answers to the question about other important problems (four options possible) also reveal that climate changes place third. In Croatia, climate changes are viewed as the most important humankind problem by $8 \%$ of the participants, which means that they see climate changes as the least serious problem, since they also consider armed conflicts and 
an economic situation to be more serious. Hagen, Middel and Pijawka (2016), in their study conducted in four European countries (Spain, the Netherlands, Great Britain and Germany), confirm that climate changes are at the lowest end of the concern list since their citizens are more preoccupied with the issues, such as: employment, crime, education, poverty, terrorism, illegal drugs, and clean energy.

Based on the above-mentioned research, it can be generally said that climate changes, when it comes to their concerns, are not in a focus of the world citizens. Their inability to recognise climate changes as a more serious problem may result from its own character, which slowly and almost invisibly changes the mere essence of the Earth eco-system. However, this does not make climate changes less important as a problem since the survival of humans is dependent on the healthy environment and, thus, questions any of its threats to their own existence, and may lead to problems in other fields of life.

\section{Perceptions of Climate Changes in the World}

\subsection{Trend in the Perceptions of Climate Changes}

Historically speaking, the cognition of climate changes dates back to the 1980s, since when people have been increasingly aware of them but have not had enough knowledge, so climate changes are often related to the problem of ozone holes. From the mid-1990s to the mid-2000s, the public became increasingly concerned about the given problem, and more versatile opinions were also made. In the mid- and late 2000s, there was a decrease in this concern, so scepticism appeared mostly in developed countries, along with the polarisation of approaches towards climate changes within countries and across them. The period of stabilisation started after 2010 although this concern is still increasing in some parts of the world (Capstick et al., 2015). This can be supported by a study in which the terms global warming and climate changes used from 2004 to 2014 were searched on the internet since Lineman et al. (2015) confirm that, in the earlier period, global warming was largely more popular than climate changes, recording a considerable growth in this trend in 2007 when the Nobel Prize for Peace was shared by Al Gore and the Intergovernmental Panel on Climate Change, as well as in 2010 when there was a significant growth with regard to the awareness of climate changes. The search for both terms, however, recorded a decrease and stagnation, including 2014. In spite of the research result obtained by Lineman, et al. (2015), climate changes have been increasingly drawing researchers' and media attention, so it can be expected that the future research will confirm the perception of its significance. 


\subsection{Perceptions of Climate Changes According to Particular Studies}

In their analysis focused on the perceptions of climate changes in the U.S.A. and Europe, Lorenzoni and Pidgeon (2006) show that, during fifteen years (since 1990), there was the widely-spread awareness of climate changes and concern about them, but climate changes were still considered to be less significant than other personal issues and social problems. It was perceived that there was a threat caused by climate changes, but that this was mainly a distant phenomenon in terms of time and space. The understanding of causes and consequences of climate changes was limited, though. An insight into the early perception of climate changes can be provided by a study, conducted in the U.S.A. in 1997 (O'Connor $\&$ Fisher, 2000), in which the wrong understanding of climate change causes was confirmed, so that even $65 \%$ of the participants recognised one of the main causes in the thinning of ozone layer. In addition, climate changes were viewed rather as a social (50\% chose 4 and 5 on the five-grade scale) than a personal (23\% chose the same grades) risk.

Due to a study conducted in 47 countries from 2005 to 2009, Kvaloy, Finseraas, and Listhaug, (2012) reveal that the participants in each country see climate changes as an important environmental problem, preceded by the care about river, lake and ocean pollution, but followed by the care about bio-diversity loss. They also show a high level of concern about climate changes since the value in each country included in the study (excluding Zambia, Rwanda and Thailand) exceeds the average (3) -4 means that climate changes are perceived as a very serious problem. In Turkey, Argentina and Burkina Faso, climate changes are perceived most seriously. Brechin and Bhandari (2011) present and analyse some of the existing studies in a larger number of countries in the world. Pew's study including 25 countries in 2009 confirms that averagely 56\% of the participants perceive global warming as a very serious problem (4 on the four-grade scale). Starting from the World Bank study, which includes 15 countries in the world, the majority of the participants in 9 countries think that they have already been affected by climate changes (58\% on average in all the countries). With regard to the agreement on climate changes among researchers, in the same 15 countries, the majority (averagely 51\%) of the participants think that the problem is already well-known and has to be urgently solved.

Studies dealing with climate changes are often conducted especially in the U.S.A. Despite the raised awareness of climate changes in the U.S.A., due to the group sample of studies conducted there from 2001 to 2008 (McCright, 2010), there has recently been confirmed that no more than 55\% of the participants think that the adverse effects of climate changes and extremes have already begun, $60 \%$ of them think that these have been caused by the human activity and believe 
that only $63 \%$ of researchers think that climate changes are occurring, indeed. However, no more than $33 \%$ of the participants are considerably concerned about climate changes, $35 \%$ of them evaluate climate changes as a threat in their lifetime, and $33 \%$ of the participants think that the seriousness of climate changes has been underestimated in media. Besides, according to a 2003 study from the U.S.A. (Leiserowitz, 2005), the participants mostly perceive climate changes as a timeand space-related distant phenomenon of moderate risk, with $68 \%$ of them being the most concerned about people in the world and the environment. Only 13\% of the participants were the most concerned about themselves, their families, or local communities. A study, conducted in the U.S.A. in 2009 (Reynolds et al., 2010), confirms that the human activity is perceived as the cause of climate changes, at least to some extent, by the majority of the participants (89\%). This is, however, a lower percentage in comparison to the one from 1992 (98\%). There is a relevant shift neither in the U.S.A. study from 2010 (Leiserowitz, Smith \& Marlon, 2010) in which no more than $63 \%$ of the participants think that climate changes are occurring, while $50 \%$ of them think that these have been caused by man. Only $39 \%$ of the participants think that the majority of researchers are aware that climate changes are occurring. The given concern is at a very low level. No more than $16 \%$ of the participants are very concerned, whereas $39 \%$ of them are concerned to certain extent.

Some studies have been also conducted in Europe. For example, in Great Britain in 2008 (Whitmarsh, Seyfang \& O'Neill, 2011), there was confirmed a high level of awareness since below $1 \%$ of the participants had never heard of climate changes. Although only $10 \%$ of the participants perceived themselves as much knowledgeable about climate changes, the majority of them (56\%) thought that they were rather knowledgeable. No more than 53\% of the participants thought that they themselves were affected by climate changes. In Japan, in 2005 (Ohe \& Ikeda, 2005), it was confirmed that the participants had also high perceptions of climate changes, and also perceived that, more likely, climate changes would affect the society rather than themselves. A more recent study, conducted in four European countries (Spain, the Netherlands, Great Britain and Germany) in 2016 (Hagen, et al., 2016), confirms that climate changes are considered to be a serious threat in Europe, that is $23 \%$ of the participants think that there is a very high risk concerning the negative consequences of climate changes (grade 5 out of 5). The study also shows that the participants recognise a very high risk of floods, droughts and forest fires in the following fifty years; they also mention a high risk of more frequent and more serious hurricanes and strong heat waves. Although people evaluate them to a somewhat lower degree, they also recognise serious threats in: the extinction of animal and plant species, famine and a lack of food, a larger number of poor individuals, problems with immigrants in certain parts of the world, diseases and epidemics, damages to the coastline, an enormous loss of 
arable land, and a negative effect on the global economy. According to the Europebased research in 2017, (Special Eurobarometer 459), even 27\% of the participants perceive climate changes as an extremely serious problem (grade 10 out of 10), while $74 \%$ of them perceive this as a very serious problem (graded from 7 to 10). The first Croatian research focused on climate changes, from 2008, (Landau, Legro \& Vlašić, 2008), confirmed that $1 \%$ of the participants had never heard of climate changes, while the majority $(55 \%)$ perceived themselves as quite familiar with them. Even $72 \%$ considered climate changes to be a very serious problem, generally viewing a big or very big predicted personal effect in the future $(54 \%$, $57 \%$ and $58 \%$ depending on the age groups, from the youngest to the oldest). In their Croatian research, Ančić, Puđak and Domazet (2013) confirmed that $70 \%$ of the participants recognised climate changes as a serious problem, while $18 \%$ of them thought that it was a much serious problem. Studying other aspects of climate changes, they confirmed that the majority of the citizens $(60 \%)$ thought that Croatia did not do much at all to fight climate changes, and that the accession to the European Union would not significantly alter the situation (almost $50 \%$ of the participants thought that Croatia would do just the same as before). Although the largest number of the participants (72\%) saw the temperature increase caused by climate changes as extremely dangerous in environmental terms, the smaller percentage (40\%) of them thought that climate changes should be given a priority in comparison to economic development. Starting from the previously mentioned research for Europe in 2017 (Special Euro barometer 459), climate changes were seen as a very serious problem (grades from 7 to 10) in Croatia by $70 \%$ of the participants, which is slightly below the European average.

It is important to mention that the awareness of climate changes is becoming also more relevant in less developed countries, such as Ethiopia (Regassa \& Stoecker, 2014), where it has been confirmed that $82 \%$ of males think that climate changes already started; this perception has been recorded in $84 \%$ of females. A slightly smaller number of them, $73 \%$ of males and $74 \%$ of females, think that climate changes have been caused by the human activity. A significant percentage of the participants, even $82 \%$, perceive climate changes as a threat to their way of living, and $68 \%$ of them also think that the adverse effects of climate changes and extremes have been underestimated. The awareness of climate changes as a term does not simultaneously mean its understanding. Although the majority of the participants in Bangladesh (Bahauddin, Rahman \& Hasnine, 2016) were familiar with the given term, their answers about its meaning were different, incorrectly reflecting the essence of the problem, i.e. only $25 \%$ of them related the term to an increase in temperature. Besides, they were deeply unaware of its consequences, $48 \%$ of them thought that it was caused by changes in the nature or by God. 


\section{Student Perceptions of Climate Changes}

There have been globally conducted several studies on student perceptions of climate changes, and some of them are mentioned in the following section. Based on a 2010 study with American students aged 18-22 (Wachholz, Artz \& Chene, 2014), $75 \%$ of the students think that climate changes are occurring now, and $81 \%$ of them recognise their cause in the human activity. Regarding their concern about the given issue, $17 \%$ of the students are very concerned, while $48 \%$ of them are concerned to some extent. Evaluating their knowledge about climate changes, the majority $(63 \%)$ report moderate or abundant knowledge; upon checking their evaluation factually, the majority, however, show very poor basic knowledge. Even $43 \%$ of them think that the ozone hole is the main cause of climate changes; $30 \%$ of them think that the majority of researchers do not agree on whether climate changes are occurring, which may be a reflection of media controversies about this topic and the strength of oil lobby; $33 \%$ of the students state that climate changes touch upon their own lives, while a slightly larger percentage (41\%) understand that these affect people all over the world. The majority (54\%) think that they have not been given enough information about climate changes during their studies, so $62 \%$ want to find out more about climate changes, whereas $23 \%$ want to receive a considerably larger amount of information. Actually, the education of young people is extremely important since a study with American students aged between 18 and 66 (a much wider range), in which their understanding of the difference between weather circumstances and climate was measured (Lombardi \& Sinatra, 2012); indicate an advancement in this understanding after a short course on global warming.

During 2011, there was conducted a study on the awareness, perceptions and beliefs of students from the U.S.A., average age 23 years, and from China, average age 20 years, (Jamelske, Barrett \& Boulter, 2013). The results show that $87 \%$ of the Chinese students and $77 \%$ of the American students think that climate changes are occurring, among them $86 \%$ of the Chinese students think that the human activity is their cause, while no more than $59 \%$ of the American students have the same opinion. Regarding their perception of how much researchers agree on climate changes, $52 \%$ think that the majority of researchers agree that climate changes are occurring, while $40 \%$ think that researchers perceive the human activity as the cause of climate changes. The percentage is slightly higher when it comes to the Chinese students, so $72 \%$ of them report on the agreement among researchers, while $70 \%$ of them see the human activity as the main cause of climate changes.

A comparative study on climate changes, including students - aged 21-30 - in Portugal, Mexico and Mozambique (Morgado, Bacelar-Nicolau, von Osten, Santos, Bacelar-Nicolau, Farooq, Alves, Soares \& Azeiteiro, 2017), confirms that 
the students in Mozambique are totally convinced in the current climate changes $(100 \%)$, while this percentage in Portugal is $98 \%$ and only $82 \%$ in Mexico. The students in Mozambique are also interested in climate changes the most (a high level of interest in 88\%), in comparison to those in Mexico (64\%) and Portugal (56\%). All the Mexican students consider climate changes to be a very important issue $(100 \%)$, while the percentage is a bit lower in Mozambique (82\%). No more than $66 \%$ of the Portuguese students think the same. Despite the previous differences, the students in each country are very much concerned (45\%-59\%). According to the obtained results, in each country, the students think that climate changes have a considerably significant influence on their local communities (72\%-82\%) and in other parts of the world (74\%-92\%); the Portuguese students mostly perceive this problem as distant in terms of space. In each country included in this study, the students think that researchers agree upon the fact that climate changes are occurring now (72\%-85\%), and almost all of them believe that the human activity represents a significant factor of climate changes (95\%-100\%). The largest number in each country think that their technical knowledge about climate changes is moderate, i.e. 53\% in Mozambique, 69\% in Mexico, and 78\% in Portugal. Despite such opinion, even $77 \%$ of the Mexican students, $56 \%$ of the Portuguese students, and $50 \%$ of the students from Mozambique still perceive the ozone hole as the main cause of climate changes. In each of the three countries, the students want to have more information about climate changes (95\%-100\%); considerably more information is required by the Mexican students (31\%), whereas this percentage is $12 \%$ in Mozambique and 7\% in Portugal.

Studying the sustainable development issues in Croatia, Rončević, Ledić and Ćulum (2008) determined that the participants largely perceived the ongoing climate changes ( $81 \%$ totally disagreed or disagreed that these would happen in the distant future). The findings obtained from students in 2011 by Hadžiselimović (2015), i.e. a larger-scale research-based, indicated, among other things, that there is a significant discrepancy in their opinions about the possible current effects on their everyday living. Apart from many participants who could not make their decisions about this question (35\%), a bit larger number of them either totally rejected or rejected this statement (42\%), while $23 \%$ of them either totally accepted or accepted this statement. Climate changes were perceived as a serious problem (70\% either totally accepted or accepted this statement), but as a personal threat (52\% the same agreement) rather than a threat to life on the Earth (71\% - the same agreement) or to the future generations ( $74 \%$ - the same agreement). Considering the school system, the majority thought that enough knowledge about climate changes was not provided at schools (76\% either totally accepted or accepted the statement), while $61 \%$ of them totally accepted or accepted the statement about their wish to learn more about climate changes. 


\section{Research Methodology}

\subsection{Questionnaire}

The questionnaire has been based on the same or questions adapted from different sources. So, three-option question 1 referred to the significance of climate changes as a serious problem of the humankind compared to other problems of the humankind (Special Euro barometer 459, 2017). Yes-no question 2 asked the participants whether they had heard about climate changes or not at all (Capstick et al., 2015). Three-option (yes, no, I don't know) questions 3, 4 and 5 included the basic knowledge about climate changes: familiarity with the ongoing changes, their primary causes and relationship with the science consensus (McCright, 2010). Question 6 considered the perceived knowledge of climate changes, i.e. how the participants evaluated this type of their knowledge, according to Leiserowitz's ET all research American's Knowledge of Climate Change (Yale University, 2010). Questions 7, 8, 9, and 10 dealt with the concern related to climate changes, including the seriousness of personal or global threat (1- no threat at all, 5 - a very serious threat), personal worry (1- not existent at all, 5 a very high degree of worry), as well as the media coverage concerning the climate changes seriousness (1- their importance too much emphasised, 5 - their importance too much underestimated) (Capstick et al., 2015, McCright, 2010). Yes-no questions 11 and 12 asked the participants whether they had become familiar with climate changes before/during schooling, or during higher education studies. Yes-no question 13 about the participants' wish to find out more about climate changes was also included, following Leiserowitz's et al. research American's Teen Knowledge of Climate Change (Yale University, 2011).

\subsection{Sample}

The participants studying economics at "Dr Mijo Mirković" Faculty of Economics and Tourism in Pula were surveyed in 2018 by using the convenient sample design, which included the undergraduate and graduate students who attended classes in more general or special courses of the stream. The questionnaire was given to the participants in the Croatian language. There were 253 students included; the total of 218 valid questionnaires was recorded in 162 (74\%) females and $56(26 \%)$ males, while 35 of them could not be taken into consideration because of their invalidity. 


\section{Results and Discussion}

In order to determine the importance that the participants ascribe to climate changes in relation to other problems which the humankind encounter today, the participants had an opportunity to choose the three most relevant problems out of eight that were offered to them. The obtained results are presented in Table 1.

Table 1:

\section{PERCEPTION OF THE IMPORTANCE OF THE HUMANKIND MAIN PROBLEMS}

\begin{tabular}{|l|c|c|}
\hline Which of these do you consider the most serious humankind problems? & n & \% \\
\hline 1. Poverty, lack of food and drinking water & 210 & 96 \\
\hline 2. International terrorism & 91 & 42 \\
\hline 3. The spread of infectious diseases & 82 & 38 \\
\hline 4. Nuclear weapon threat & 80 & 37 \\
\hline 5. Armed conflicts & 69 & 35 \\
\hline 6. Climate changes & 66 & 30 \\
\hline 7. Economic situation & 36 & 17 \\
\hline 8. Increasing population & 20 & 9 \\
\hline
\end{tabular}

Source: Own calculation, $\mathrm{n}=218$

The results show that 210 participants (96\%) consider poverty, lack of food and drinking water to be the most important humankind problems, which is unquestionably the most frequently perceived by the participants. Climate changes are the sixth-ranked, perceived by 66 participants (30\%) as a serious problem. The least important problems, as perceived by the participants, include the economic situation (36 participants $-17 \%$ ) and the growing number of inhabitants (20 participants $-9 \%$ ). Although the results are not completely comparable since three answers were required in this study and four is the largest number required in the previously mentioned Special Euro barometer 459 studies (EC, 2017), the current population of students view climate changes as less important (sixth-ranked) when compared to the average value of perceptions in the European countries (thirdranked). Despite an unfavourable economic situation in Croatia, it is interesting to note that the students do not perceive the economic situation as a serious problem of the humankind. 
All the participants $(217-99.5 \%)$, except just one, report that they have heard about climate changes, coinciding with the finding from a British study conducted in 2008 (Whitmarsh et al., 2011).The basic knowledge about climate changes of the students who have heard about them is shown in Table 2.

Table 2.

\section{THE BASIC KNOWLEDGE OF CLIMATE CHANGES}

\begin{tabular}{|l|r|r|}
\hline Do you think that climate changes are happening? & \multicolumn{1}{c|}{ n } & \multicolumn{1}{c|}{$\%$} \\
\hline Yes & 206 & 95 \\
\hline No & 3 & 1 \\
\hline I don't know & 8 & 4 \\
\hline If yes, what is their main cause? & 163 & \\
\hline Human activities & 36 & 79 \\
\hline Natural cycles & 7 & 3 \\
\hline I don't know & & \\
\hline $\begin{array}{l}\text { Do you agree with the majority of scientists who think that climate } \\
\text { changes have been caused by human activities? }\end{array}$ & 167 & 81 \\
\hline Yes & 17 & 8 \\
\hline No & 22 & 11 \\
\hline I don't know & & \\
\hline
\end{tabular}

Source: Own calculation, $\mathrm{n}=217, \mathrm{n}=206$

Based on Table 2, it is clear that the large majority, i.e. 206 participants (95\%) among those who have heard about climate changes think that these are really occurring. The finding, despite slight deviations, coincides with what has been obtained in the study conducted in Portugal (98\%), Mexico (82\%), and Mozambique in which all the participants have this opinion (Morgado et al., 2017). The values from the current and the above-mentioned research are relatively high when compared to the previous research with students, i.e. the one conducted in the U.S.A. in 2010 (Wachholz et al., 2014), as well as the one conducted in the U.S.A. and China in 2011 (Jamelske et al., 2013), which may indicate the growing awareness in the world of the fact that climate changes are occurring, indeed.

Being aware of the fact that climate changes are really at work, as reported by 206 participants, the majority of them, i.e. 163 of them (79\%) see their main cause in the human activity. The current result is slightly lower than in the previously mentioned studies in Portugal, Mexico and Mozambique (95\%-100\%), but higher in comparison with the studies conducted in the U.S.A. (59\%) and China 
(86\%) in 2011 (Jamelske et al., 2013), as well as in the U.S.A. in 2010 (Wachholz et al., 2014). Based on the given findings, it can be seen that recently the students have become more knowledgeable about climate changes being caused by the human activity. Therefore, the better awareness of man as the main agent of climate changes is the foundation for taking steps by all the relevant subjects, including companies which can change their performance methods, individuals who change their consumption approaches, and governments that have a decisive role in issuing laws as the bottom-line at which certain practices are acceptable.

The knowledge that the participants possess about the agreement among researchers reflects the study result according to which also the majority of 167 participants (81\%) supporting the claim that the majority of researchers recognise the human activity as the main cause of climate changes. There is certain deviation, since a bit fewer participants believe that climate changes are caused by the human activity, when related to the perceived attitudes of researchers, but also a bit more participants who claim that they have no idea about the attitudes of scientific and professional public, when related to the previous answer. The obtained result is not much good, and indicates the lacking knowledge of studies and documents dealing with climate changes. Yet, the current score is significantly higher in comparison with the study in the U.S.A. (40\%) and China (70\%) (Jamelske, et al., 2013), but the time component should be taken into account.

Regarding their perceived knowledge of climate changes, the participants observe that they are informed about the facts related to climate changes just a bit below the average (means 2.84), and $17 \%$ of them think that their knowledge is at a high or a very high level (grades 4 or 5); only $1 \%$ believe that their knowledge is at a very high level. This result coincides with what has been found in the study in Portugal, Mexico and Mozambique, with the majority claiming that their knowledge of climate changes is moderate (Morgado et al., 2017).

Because of different scales and interpretations, the following results in Table 3 considering the concern about climate changes are not directly comparable with the majority of those obtained in the previous studies. 
Table 3:

\section{CONCERN ABOUT THE CLIMATE CHANGES}

\begin{tabular}{|l|c|c|}
\hline Statements/ questions & Mean & St. dev. \\
\hline $\begin{array}{l}\text { How much do you consider climate changes as a serious threat to the } \\
\text { humankind? }\end{array}$ & 4.00 & 0.74 \\
\hline $\begin{array}{l}\text { How much do you consider climate changes as a serious threat to you and } \\
\text { your family? }\end{array}$ & 3.42 & 1.04 \\
\hline How much are you personally worried about climate changes? & 3.12 & 0.99 \\
\hline $\begin{array}{l}\text { Do you think that the media coverage is objective when it comes to the } \\
\text { seriousness of climate changes? }\end{array}$ & 3.57 & 0.08 \\
\hline
\end{tabular}

Source: Own calculation, $n=206$

Using the five-point scale, climate changes are considered to be a very serious threat to the humankind (means 4.00 ), with even $77 \%$ of the participants choosing 4 and 5 , and $26 \%$ of them choosing 5 . Climate changes are a bit less considered as a serious threat to the personal safety and family (means 3.42 ), with $50 \%$ choosing 4 and 5, and $15 \%$ choosing the highest grade (5). The given finding coincides with that by Hadžiselimović (2015), showing that the Croatian students perceive climate changes as a less serious personal than a threat to the humankind. The personal concern seems to be even less serious (means 3.12), but above the average, with $35 \%$ choosing 4 or 5 , and with $9 \%$ choosing 5 . It can be stated that the results do not considerably deviate from the findings obtained from adults in 25 countries in the world, with $56 \%$ of the participants thinking that global warming is a very serious problem (Brechin \& Bhandari, 2011); according to the Special Euro barometer 459 (EC, 2017), the same opinion was shared by $75 \%$ of the participants. It is indicative that, as in almost any previous study, the students perceive climate changes as a serious threat rather to the humankind than to themselves and their families (Morgado et al., 2017, Wachholz et al., 2014). A gap between the abovementioned perceptions is even wider in the studies including the complete population, but these were conducted in the earlier periods (Lorenzoni, \&Pidgeon, 2006, Leiserowitz, 2005, Ohe \& Ikeda, 2005). However, one of the more recent studies in Ethiopia (Regassa \& Stoecker, 2014) on the population of adults shows a deviation from the results valid for developed countries, along with the current study, in which the participants think that climate changes are a threat to their life-style (82\%), as well as that their effects are underestimated (68\%). Although climate changes continue to affect non-developed countries to the largest degree, it is impossible to deny their effects more and more visible also in the parts of the world 
where developed countries are located, so a change in the perception of personal dangers can be also expected.

In comparison to the comprehensive studies by McCright (2010) in the U.S.A. (means 0.49, grades 0-1), the participants mostly think that the serious character of climate changes is underestimated in the media coverage (means 3.57). In accordance with this, $50 \%$ of the participants claim that their importance is very and too much underestimated (grades 4 or 5); while $3 \%$ of them think that their importance is too much emphasised (grade 1). Therefore, climate changes are becoming increasingly obvious across the world, and it will be necessary to pay more media attention to them.

Finally, the acquisition of formal knowledge regarding climate changes was researched by asking the participants whether they had dealt with this topic during university studies; 34 participants (17\%) provided the positive answer, while 172 participants $(83 \%)$ provided the negative answer. However, there are significantly more students who encountered the topic of climate changes earlier in their education, 173 participants with the positive answer (84\%), and 33 participants with the negative answer (16\%). The participants are largely open to new ideas about climate changes, so 169 participants $(82 \%)$ answered that they would like to learn more about climate changes, while 37 participants $(18 \%)$ answered that they would not like this. This percentage is higher when compared to the study conducted with the Croatian students by Hadžiselimović (2015), although a bit lower than the one in the previously-mentioned study in Portugal, Mexico and Mozambique (Morgado et al., 2017). Therefore, the society is responsible for providing as much information as possible in a range of manners when young people and the given problem are discussed.

\section{Contributions and Limitations of the Paper, and the Future Research}

Studies on the perceptions of climate changes have been conducted for several decades, although there have not been many of them including the student population. However, students can be seen as a significant population since, being educated individuals, they are the powerful agents of social changes who are able to consider this particular issue in a positive manner. So, it is equally important to discover their perceptions, and to educate them about the real climate changes. The results of the current study indicate that students possess some knowledge acquired in the previous education and a lack of attention being paid to them within academic education. The students attending the Faculty of Economics and Tourism "Dr. Mijo Mirković" in Pula can learn about climate changes during the first-year graduate study of the Tourism stream, within the course of Sustainable Tourism, that of the Management and entrepreneurship stream within the course of 
Sustainable Development Management, and that of the Economics stream within the course of Environmental Economics; the third-year undergraduate students of the Marketing stream have the optional course of Sustainable Marketing; all this is actually enough. The teaching contents at all educational levels should, therefore, include more information about climate changes, which is one of the pre-requisites for changing the society and for solving the already pretty much serious problem of climate changes as better as possible.

The paper should contribute to determining the student perceptions of climate changes, as a supplement to a small number of studies including the given population; also, to contribute to a small number of studies into the perception of climate changes in Croatia. The limitation of the paper lies in the small sample based on the students of economics at "Dr. Mijo Mirković" Faculty of Economics and Tourism in Pula. The conclusions would be thus more valid if the study had included other faculties of economics in Croatia. It would be interesting to conduct a study with the students of other profiles in order to determine whether there are certain differences between them. Besides, another study would enable a comparison of perceptions among teenagers, students and adults, and, thus, provide an insight into generation-like differences.

The given study could be the starting point for more detailed research into the connections and relations between particular included items. Based on some studies (Bord, O'Connor \& Fisher, 2000, Kahlor \& Rosenthal, 2009, Guy, Kashima, Walker \& O'Neill, 2014, Shao et al., 2016) and the assumptions of the current authors, the following relations can be later taken into account:

1. The items covering the knowledge of the ongoing climate changes, caused by the human factor, and the knowledge of consensus among scientists are related to the concern about climate changes in terms of the perception of seriousness of climate changes as a personal threat and a threat to the humankind, personal worry about climate changes and estimation of the significance of climate changes in the media.

2. The knowledge of science consensus is related to the knowledge about the ongoing climate changes and the human activities as their cause

3. The perception of seriousness of climate changes as a personal and threat to the humankind, and personal worry are related to the wish to acquire more knowledge about climate changes

4. Familiarity with the topic of climate changes in schooling, before and during higher education are related to the knowledge of the ongoing climate changes, the human factor as their cause, and the acceptance of knowledge showing that the majority of scientists think that climate changes are happening caused by the human factor 
5. Familiarity with the topic of climate changes in schooling, before and during higher education are related to the perception of climate changes as a serious threat to the humankind, personal threat and personal worry about climate changes and the perception of estimated significance of climate changes in the media

6. Familiarity with the topic of climate changes before and during higher education is related to the perceived knowledge of climate changes

7. Perceived knowledge of climate changes is related to the knowledge of the ongoing climate changes, the human activities as their cause, and the agreement among scholars that the ongoing changes are caused by the human activities

The current study approach is not much deep when it comes to the real knowledge of the causes and consequences of climate changes. Namely, the majority of adults, also students, are aware that climate changes have been caused by the human activity and also represent a serious threat, but only good knowledge of their cause can lead to the right actions, at least to mitigate the present climate changes and also allow the observed consequences, which touch upon everyman's life, to motivate people to take the necessary steps.

\section{Literature}

Ančić, B., Puđak, J. \& Domazet, M. (2016). Vidimo li klimatske promjene u Hrvatskoj? Istraživanje stavova o nekim od aspekata klimatskih promjena u hrvatskom društvu. Hrvatski meteorološki časopis, 51, 1-72. Available at: https://hrcak.srce.hr/168219

Bahauddin, K., Rahman, N. \& Hasnine, T. (2016). Environmental Reviews and Case Studies: Public Perception, Knowledge, and Participation in Climate Change Adaptation Governance in the Coastal Region of Bangladesh Using the Social Ecological Inventory (SEI) Tool. Environmental Practice, 18(1), 32-43. DOI: 10.1017/S1466046615000393

Bodzin, A.M., Anastasio, D., Sahagian, D., Peffer, T., Dempsey, C. \& Steelman, R. (2014). Investigating Climate Change Understandings of Urban MiddleLevel Students. Journal of Geoscience Education, 62(3), 417-430. DOI: 10.5408/13-042.1

Bord, R.J., O'Connor, R.E. \& Fisher, A.(2000). In what sense does the public need to understand global climate change?. Public Understanding of Science, 9(3), 205-218. DOI: /10.1088/0963-6625/9/3/301 
Capstick, S., Whitmarsh, L., Poortinga, W., Pidgeon, N. \& Upham, P. (2015). International trends in public perceptions of climate change over the past quarter century. WIREs Climate Change, 6(1), 35-61. DOI: 10.1002/wcc.321

European Commission (2017). Special Eurobarometer 459, Climate Change, September 2017, https://ec.europa.eu/clima/sites/clima/files/support/docs/report_2017_en.pdf (21.2.2017.)

European Commission. Climate change consequences, https:/ec.europa.eu/clima/ change/consequences_en (9.1.2019.)

Guy, S., Kashima, Y., Walker, I. \& O’Neill, S. (2014). Investigating the effects of knowledge and ideology on climate change beliefs, European Journal of Social Psychology, 44, 421-429. DOI: 10.1002/ejsp.2039

Hadžiselimović. Dž. (2015). Klimatske promjene u svijesti istarskih studenata. Klima se mijenja, a i mi..., Društvo psihologa Istre, Pula. Available at: http:// dpi.hr/wp-content/uploads/2012/09/Klimatske-promjene-u-svijesti-istarskihstudenata.pdf

Hagen, B., Middel, A. \& Pijawka, D. (2016). European Climate Change Perceptions: Public support for mitigation and adaptation policies. Environmental Policy and Governance, 26(3), 170-183. DOI: 10.1002/eet.1701

Harker-Schuch, I. \& Bugge-Henriksen, C. (2013). Opinions and Knowledge About Climate Change Science in High School Students. Ambio, 42(6), 755-766. DOI: $10.1007 / \mathrm{s} 13280-013-0388-4$

Jamelske, E., Barrett, J. \& Boulter, J. (2013). Comparing climate change awareness, perceptions, and beliefs of college students in the United States and China. Journal of Environmental Studies and Sciencies, 3(3), 269-278. DOI: 10.1007/s13412-013-0144-X

Kahlor. L. \& Rosenthal, S. (2009). If We Seek, Do We Learn? Science Communication, 30(3), 380-414. DOI: 10.1177/1075547008328798

Kvaloy, B., Finseraas, H. \& Listhaug, O. (2012). The publics' concern for global warning; A cross-national study of 47 countries. Journal of Peace Research, 49(1), 11-22. DOI: 10.1177/0022343311425841

Landau, S, Legro, S. \& Vlašić, S. (2008). Dobra klima za promjene. Klimatske promjene i njihove posljedice na društvo i gospodarstvo u Hrvatskoj. UNDP Hrvatska. Available at: http://klima.hr/razno/priopcenja/NHDR_HR.pdf

Leiserowitz, A. A., Smith, N. \& Marlon, J.R. (2011). American Teen Knowledge of Climate Change. Yale University, New Haven, CT: Yale Project on Climate Change Communication, http://environment.yale.edu/uploads/americanteens-knowledge-of-climate-change.pdf (15.3.2018.)

Leiserowitz, A. A., Smith, N. \& Marlon, J.R. (2010). American's Knowledge of Climate Change. Yale University, New Haven, CT: Yale Project on 
A. NEFAT, D. BENAZIĆ: The student perceptions, concern and knowledge with regard to climate changes in Croatia EKONOMSKI PREGLED, 70 (5) 723-742 (2019)

Climate Change Communication, http://environment.yale.edu/climate/files/ ClimateChangeKnowledge2010.pdf (20.3.2018.)

Leiserowitz, A. A. (2005). American Risk Perceptions: Is Climate Change Dangerous?. Risk Analysis, 25(6), 1433-1442. DOI: 10.1111/j.15406261.2005.00690.x/full

Lineman, M., Do, Y., Kim, J.Y. \& Joo, G.-J. (2015). Talking about Climate Change and Global Warming. PloS ONE, 10(9), 1-12. DOI: 10.1371/journal. pone.0138996

Lombardi, D. \& Sinatra, G.M. (2012). College Students' Perceptions About the Plausibility of Human-Induced Climate Change. Research in Science Education, 42(2), 201-217. DOI: 10.1007/s11165-010-9196-Z

Lorenzoni, J. \& Pidgeon, N.F. (2006). Public View of Climate Change: European and USA Perspective. Climatic Change, 77(1-2), 73-95. DOI: 10.1007/s10584006-9072-z

McCright, A.M. (2010). The effects of gender on climate change knowledge and concern in the American public. Population and Environment, 32(1), 66-87. DOI: 10.1007/s11111-010-0113-1

Morgado, F., Bacelar-Nicolau, P., von Osten, J.R., Santos, P., Bacelar-Nicolau,L., Farooq, H., Alves, F., Soares, A. \& Azeiteiro, U. (2017). Assessing university student perceptions and comprehension of climate change (Portugal, Mexico, Mozambique). International Journal of Climate Change Strategies and Management, 9(3), 316-336. DOI: 10.1108/IJCCSM-08-2016-0123

Ohe, M. \& Ikeda, S. (2005). Global Warming: Risk perception and Risk-Mitigating Behavior in Japan. Mitigation and Adaptation Strategies for Global Change, 10(2), 221-236. DOI: 10.1007/s11027-005-6138-6

Pitpitunge, A.D. (2013). Students' perceptions about climate change. Asian Journal of Biology Education, 7, 2-11, http://www.aabe.sakura.ne.jp/Journal/Papers/ Vol7/02\%20Pitpitunge.pdf(15.6.2018.)

Radna verzija Strategije prilagodbe klimatskim promjenama u Republici Hrvatskoj za razdoblje do 2040. godine s pogledom na 2070. godinu (Zelena knjiga) (2017). Ministarstvo zaštite okoliša i energetike, Hrvatska. Available at: http:// prilagodba-klimi.hr/wp-content/uploads/2017/07/Strategija-prilagodbe-k.p.ZELENA-KNJIGA-03-07-2017.pdf

Regassa, N. \& Stoecker, B.J. (2014). Attitude and Risk Perceptions about Climate Change in Farming Communities in Sourhern Ethiopia. Environmental Practice, 16(1), 29-36. DOI: 10.1017/S1466046613000628

Reynolds, T.W., Bostrom, A., Read, D. \& Morgan, M.G. (2010). Now What Do People Know About Global Climate Change? Survey Studies of Educated 
Laypeople. Risk Analysis, 30(10), 1520-1538. DOI: 10.1111/j.15396924.2010.01448.x

Rončević, N., Ledić, J. \& Ćulum, B. (2008). "Nisam sigurna što je, ali je bitno" analiza stavova studenata Sveučilišta u Rijeci o održivom razvoju, Suvremene TEME, 1(1), 62-75. Available at: https://hrcak.srce.hr/35232

Shao, W., Garand, J.C., Keim, B. D. \& Hamilton, 1. C. (2016). Science, Scientists, and Local Weather: Understanding Mass Perceptions of Global Warming, Social Science Quarterly, 97(5), 1023-1057. DOI: 10.111/ssqu.12317

Smith, T.W., Kim, J., \& Son, J. (2017). Public Attitudes toward Climate Change and Other Environmental Issues across Countries. International Journal of Sociology, 47(1), str. 62-80. DOI: 10.1080/00207659.2017.1264837

Wachholz, S., Artz, N. \& Chene, D. (2014). Warming to the idea: university students' knowledge and attitudes about climate change. International Journal of Sustainability in Higher Education, 15(2), 128-141. DOI: 10.1108/ IJSHE-03-2012-0025

Whitmarsh, L., Seyfang, G. \& O'Neill, S. (2011). Public engagement with carbon and climate change: To what extent is the public 'carbon capable'?. Global Environmental Change, 21(1), 56-65. DOI: 10.1016/j.gloenvcha.2010.07.011

\author{
PERCEPCIJE, BRIGA I ZNANJE STUDENATA \\ O KLIMATSKIM PROMJENAMA U HRVATSKOJ
}

Sažetak

Svrha rada je istražiti percepcije studenata o klimatskim promjenama što je učinjeno na uzorku studenata poslovne ekonomije u Hrvatskoj. Rad obuhvaća procjenu značaja klimatskih promjena u odnosu na druge probleme čovječanstva, ispitivanje percepcija o glavnim uzrocima, ozbiljnosti pojave, zabrinutost, procjenu vlastitog znanja, izvori stečenih spoznaja tijekom obrazovanja te otvorenost novim informacijama. Glavni nalazi istraživanja ne odstupaju bitno od novijih istraživanja te vrste u odnosu na populaciju studenata te cjelokupnu populaciju, ali u odnosu na istraživanja cjelokupne populacije iz ranijih godina uočava se napredak u razumijevanju klimatskih promjena. Teorijski, rad predstavlja presjek tematike klimatskih promjena od smještanja kao svjetskog problema do percepcije cjelokupne populacije u trendu i prema pojedinim istraživanjima na cjelokupnoj populaciji i posebno populacije studenata. Praktička implikacija je da bi osnovom svjesnosti ozbiljnosti klimatskih promjena i voljnosti stjecanja novih znanja studentima trebalo pružiti opsežnije obrazovanje kako bi kao akademski građani u budućnosti bili sposobni donositi relevantne odluke u svezi pitanja okoliša. Ograničenje rada je maleni uzorak na studentima ekonomije, a originalnost istraživanja jedinstveno oblikovan predmet istraživanja kombinacijom više prethodnih istraživanja kao doprinos istraživanju percepcija o klimatskim promjenama studenata. Također, osnovom uključenih stavki predlažu se daljnja istraživanja njihovih veza.

Ključne riječi: klimatske promjene, percepcije, studenti, Hrvatska 